Acta vet. scand. $1984,25,445-461$.

From the Department of Obstetrics and Gynaecology, Animal Breeding and Genetics, and Clinical Chemistry, Swedish University of Agricultural Sciences, Uppsala.

\title{
POSTPARTUM REPRODUCTIVE PERFORMANCE IN DAIRY COWS
}

I: INFLUENCE OF ANIMAL, BREED AND PARITY

\author{
By \\ Kjell Larsson, Lennart Jansson, Britt Berglund \\ Lars-Eric Edqvist and Hans Kindahl
}

LARSSON, K., L. JANSSON, B. BERGLUND, L.-E. EDQVIST and H. KINDAHL: Postpartum reproductive performance in dairy cows. I: Influence of animal, breed and parity. Acta vet. scand. 1984, 25, 445461. - The purpose of this study was to evaluate the influence of animal, breed and parity on postpartum reproductive functions in dairy cows. A total of 141 cows were included in the experiment, which was carried out as part of a study on traits affecting longevity in Swedish dairy cows. The cows belonged to 4 different breed-groups and were 1 st to 5th calvers. The duration of the study was 3 years and 44 cows were followed during 1 postpartum period, 49 cows during 2 consecutive periods, 43 cows during 3 periods and 5 cows during 4 periods.

The cows were clinically examined, by rectal palpation, at 10-day intervals between calving and first AI, which was at first normal oestrus more than 50 days after calving. External signs of heat were checker and recorded three times daily by the herdsmen. Blood samples for progesterone assay were taken at days 10, 15 and 20 after calving and thereafter every 10th day until first AI. Samples taken at days 10, 15 and 20 were also assayed for content of 15-keto-13,14-dihydro-PGF $2 \alpha$.

Heat detection records, records from clinical examinations and plasma progesterone assays were chronologically compiled for each postpartum period and based on this, intervals between calving and postpartum ovulations, recorded uterine involution, 1st and subsequent oestrus and regular reproductive functions were estimated. Leastsquares methods were used for the statistical evaluation of data.

The results indicate a large variation within and between cows in postpartum reproductive performance. In the total material 1st ovulation occurred before recorded uterine involution and there was a close relationship between 1st ovulatory oestrus and the onset of regular reproductive functions. The interval between calving and 1st ovulation significantly influenced the length of the first cycle in the sense that a large proportion of the early ovulating cows had a short interval between 1 st and 2 nd postpartum ovulations. The large variations were also evident in the plasma levels of 15-keto-13,14-dihydro-PGF $2 \alpha$. There was a marked decline between days 10 and 15 postpartum and most cows were close to basal levels at 20 days postpartum.

The individual cow had a significant influence on intervals from calving to recorded uterine involution, 1 st ovulatory oestrus, regular 
reproductive functions and conception. The breed influence was significant for intervals between calving and 1st ovulation and recorded uterine involution whereas the parity of the cow only influenced the interval between calving and recorded uterine involution.

ovulations; uterine involution; oestrus.

Calving intervals of about 1 year are corsidered economically optimal for dairy cows (Zeddies 1982). In Sweden the average interval between calving and last $\mathrm{AI}$ is 109 days ( $S H S$ 1983) and consequently the average calving intervals is longer than 1 year. To avoid low pregnancy rate at first AI the Swedish AI associations recommend inseminations to commence at the earliest 8 weeks postpartum and the average interval between calving and first AI is in practice 83 days (SHS 1983). Early postpartum breeding is one way to decrease calving intervals (Whitmore et al. 1974). However, conception rate for the very early inseminations is low (e.g. Britt 1975).

Cyclic ovarian activity, completed uterine involution and apparent external signs of heat are prerequisites for conception. Numerous studies have been performed to investigate reproductive functions in postpartum cows (for reviews, see Graves et al. 1968, Morrow et al. 1969a, Garcia 1982). Apparently, factors like milk yield, management, postpartum disease and calving season influence the resumption of regular reproductive functions. In a recent study (Fonseca et al. 1983) differences between Jersey and Holstein cows were indicated in the relationship between milk yield and days open. Thus, also the breed of the cow is likely to influence postpartum reproductive performance. In all studies performed, a great variability between animals is indicated in postpartum reproductive performance. Basic descriptive information concerning postpartum reproductive events is an important background for herd health programs as well as for advice concerning the optimal interval between calving and first AI. The purpose of the present study was to evaluate the influence of animal, breed and parity on postpartum reproductive functions in Swedish dairy cows, kept under standardized managerial conditions. Part of the data have been included in previous reports (Berglund et al. 1980a, Kindahl et al. 1982, Garcia \& Larsson 1982, Larsson et al. 1982). 


\section{MATERIALS AND METHODS}

The investigation was part of an experiment aimed at studying traits affecting longevity in Swedish dairy cows (cf. Berglund et al. 1980b). A total of 141 cows calving between October 1978 and December 1981 were included. The cows were of the Swedish Red and White Breed (SRB), the Swedish Friesian Breed (SLB), first generation crosses between these two breeds $(\mathrm{SRB} \times \mathrm{SLB}, \mathrm{SLB} \times$ SRB) and the Swedish Jersey Breed (SJB). The cows were 1st to 5 th calvers and a total of 291 postpartum periods were examined. The distribution of animals in breeds and parities is presented in Table 1. The animals within each breed group were selected to be representative for the breed. Forty-four cows were examined during 1 postpartum period, 49 cows during 2 consecutive periods $(1+2: 33 ; 2+3: 8 ; 3+4: 8), 43$ cows during 3 consecutive periods $(1+2+3: 16 ; 2+3+4: 18 ; 3+4+5: 9)$ and 5 cows during 4 consecutive periods $(1+2+3+4: 4 ; 2+3+4+5: 1)$.

Table 1. Distribution of postpartum periods among breeds and lactations.

\begin{tabular}{|c|c|c|c|c|c|c|c|}
\hline \multirow{2}{*}{ Breed } & \multicolumn{6}{|c|}{ Number of periods in lactation } & \multirow{2}{*}{$\begin{array}{l}\text { No. of } \\
\text { animal }\end{array}$} \\
\hline & 1 & 2 & 3 & 4 & 5 & Total & \\
\hline SRB & 37 & 33 & 25 & 16 & 3 & 114 & 55 \\
\hline SLB & 22 & 14 & 11 & 5 & 1 & 53 & 34 \\
\hline $\mathrm{SRB} \times \mathrm{SLB}$ & 13 & 18 & 20 & 10 & 4 & 65 & 26 \\
\hline SJB & 17 & 17 & 14 & 9 & 2 & 59 & 26 \\
\hline Total & 89 & 82 & 70 & 40 & 10 & 291 & 141 \\
\hline
\end{tabular}

Management of the herd

The cows were tied in stalls during the entire experiment. Outdoor exercise in a paddock was allowed twice weekly from April to November. Roughage (hay and grass-silage) was fed according to body weight. Depending on roughage quality 1.5 $1.7 \mathrm{~kg}$ dry matter per $100 \mathrm{~kg}$ live weight was given with equal proportions of dry matter from hay and silage. The concentrate mixture contained oats $(36 \%)$, barley $(36 \%)$, soybean meal $(13 \%)$, rapeseed meal $(6 \%)$, wood molasses $(7 \%)$ and dicalciumphosphate $(2 \%)$. The energy content was 11.3 MJ metabolizable energy per $\mathrm{kg}$ and $11.9 \mathrm{~g}$ digestible crude protein per MJ metabolizable energy. Three weeks before expected calving the rations were increased and after calving all cows received 
$5.6 \mathrm{~kg}$ concentrate mixture corresponding to a production of 11 $\mathrm{kg}$ fat corrected milk (FCM). During the first weeks of lactation concentrate rations were increased by $0.4 \mathrm{~kg} / \mathrm{day}$ and thereafter given according to Swedish standards for milk production (5.0 MJ and $60 \mathrm{~g}$ digestible crude protein per $\mathrm{kg}$ FCM).

Milking was twice daily with approximately $9 \mathrm{~h}$ between morning and afternoon milking.

External signs of heat were checked 3 times daily (morning, noon, evening) by the herdsmen. A register sheet including 11 different oestrus signs was used and the recorded data were utilized in the subsequent evaluation.

\section{Clinical examinations and hormone assays}

All cows were clinically examined at 10 day interval between calving and first AI, beginning at the earliest 7 days after parturition. The examination included inspection of vulva and perineum, rectal palpation of cervix, uterus and ovaries. At the first examination, as well as in cases of a purulent vaginal discharge, vaginoscopy was performed. Cows were inseminated at first normal heat after 50 days postpartum and all inseminations were performed by AI technicians employed by the local AI association. Cows that returned to oestrus after their third AI were reexamined before being inseminated the 4th time. All cows were palpated for pregnancy at 6 weeks after AI and in any doubtful case the examination was repeated $\mathbf{1 0}$ days later.

All clinical findings were recorded and no information from the clinical examinations was given to the herdsmen unless it was requested due to abnormal vaginal discharge or abnormal oestrus.

Cows with signs of systematic disease were examined and treated by the ambulatory clinic of the Veterinary College.

Reproductive disorders were diagnosed and treated by the investigators with the exception of cases of acute metritis with signs of systemic illness. The following diagnostic criteria and treatments were used. A diagnosis of "endometritis" was made in cases with a thick-walled uterus, often with a small amount of palpable content. Most of these cows had a purulent vaginal discharge and vaginoscopy revealed a reddening of the cervix. Cows that showed these symptoms were not treated before 30 days after calving and in cases of spontaneous recovery before day 30 postpartum it was not recorded as endometritis. Cows 
with endometritis and a palpable corpus luteum (CL) were treated with $\mathrm{PGF}_{2 \alpha}$ (Dinolytic ${ }^{\circledR}, \mathrm{Upjohn}$ ) or its analog cloprostenol (Estrumat $\Theta$, Leo) and cows without a palpable CL were treated with an intramuscular injection of $2.5 \mathrm{mg}$ oestradiolbenzoate unnless they were judged as being in prooestrus or oestrus, in which cases the development of a CL was awaited and the prostaglandin treatment was used, if necessary. "Ovarian cysts" were defined as large $(>2.5 \mathrm{~cm})$ follicular structures. No treatment was attempted unless the cysts persisted for more than 10 days and not earlier than 6 weeks postpartum. Treatment was by manual rupture (year 1) and later by 50 or $100 \mu \mathrm{g}$ GnRH (Nialutin, Novo AS, Copenhagen).

The reproductive organs from all cows culled during the experiment were carefully examined post mortem and histological examination of the endometrium was always performed.

Blood samples for hormone assays were taken by venipuncture (v. jugularis) into heparinized Vacutainer tubes at days 10, 15, 20 and thereafter every 10th day until 1st AI. All cows inseminated more than 3 times were blood sampled at the day of subsequent $\mathrm{AI}$. The tubes were centrifuged within $30 \mathrm{~min}$, the plasma was removed and stored at below $-20^{\circ} \mathrm{C}$ until hormone assay. All samples were assayed for content of progesterone by radioimmunoassay (Kindahl et al. 1976). Samples taken on day 10,15 and 20 postpartum were assayed for centent of 15 -keto13,14-dihydro-PGF ${ }_{2 \alpha}$ by radioimmunoassay (Kindahl et al. 1976).

\section{Treatment and evaluation of data}

Heat detection records, recording from clinical examinations and plasma progesterone levels were chronologically compiled for each postpartum period. Intervals between calving and recorded uterine involution, 1st and subsequent ovulations, 1st and subsequent oestrus, 1st ovulatory oestrus and regular reproductive functions were estimated for each postpartum period. The following criteria were used for the estimates: "Uterine involution" was recorded as complete when the uterus was almost symmetric, its position was within or at the edge of the pelvic cavity, its size reduction was completed and the cranial cervix diameter was in most cases $5 \mathrm{~cm}$ or less; "days of ovulation" were estimated on the basis of palpable CL, plasma progesterone levels, occurrence of postoestrus bleeding, successful insemination or signs of heat. The day before postoestrus bleeding or the day after successful 
AI was considered as the day of ovulation. In the absence of any of these criteria a CL with a diameter of at least $15 \mathrm{~mm}$ was considered to be palpable at the earliest 5 days after ovulation and plasma progesterone levels above $0.5 \mathrm{nmol} / \mathrm{l}$ as indicative of a functional CL; "oestrus" was defined as when the cow showed several signs of heat and the general expression of her symptoms was scored as at least 2 in a scale from 0 (no heat) to 4 (very strong signs of heat); "ovulatory oestrus" was oestrous periods that where followed by the development of a CL or luteal phase; "regular reproductive function" was defined as when the cow had an ovulatory oestrus for the first time at or after the day of recorded uterine involution. All cows with recorded regular reproductive functions continued to cycle regularly or conceived at subsequent $\mathrm{AI}$.

Statistical analyses were performed by least-squares methods as applied in the GLM-procedure in the Statistical Analysis System (SAS, Helwig \& Council 1979). In the analyses of variance the full model included the effects of breed, cow within breed, parity, season of calving and score for calving difficulty. In a preliminary analysis the effect of score for calving difficulty and the season of calving as well as two-factor interactions between breed and parity were found to be non-significant for all of the measures tested. Therefore these effects were not included in the final analysis. The reduced model was applied on data from cows with at least 2 consecutive postpartum periods. The following model was used in the final analysis:

$$
\mathrm{Y}_{\mathrm{ijkl}}=\mu+\mathrm{b}_{\mathrm{i}}+c_{\mathrm{ij}}+\mathrm{p}_{\mathrm{k}}+\mathrm{e}_{\mathrm{ijkl}}
$$

$\mathbf{Y}_{\mathrm{ijkl}}=$ the ijkl'th observation

$\mu=$ least-squares mean

$b_{i}=$ fixed effect of the $i$ 'th breed, $\Sigma=b_{j} 0, i=1,4$

$b_{i j}=$ random effect of the j'th cow nested within the $i^{\prime}$ th breed, mean $=0$ and variance $=\sigma^{2}$

$p_{k}=$ fixed effect of the k'th parity, $\Sigma p_{k}=0, k=1,4$

$\mathrm{e}_{\mathrm{ijkl}}=$ residual random term with mean $=0$ and variance $=\sigma_{\mathrm{e}}^{2}$.

Parity denotes parity $1,2,3$ and $\geq 4$.

The correlations betwcen measures of postpartum reproductive performance were computed from the residuals after corrections for the effects of breed, cow within breed and parity. 
The coefficient of determination $\left(R^{2}\right)$ was adjusted for the number of independent variables included in the model according to the formula described by Pease (1966).

\section{RESULTS}

The results presented here (Tables 2, 7 and 8 ) indicate a large variation within and between cows in postpartum reproductive performance. In the total material 1st ovulation occurred before recorded uterine involution and there was a close relationship between 1st ovulatory oestrus and the onset of regular reproductive functions. The interval between calving and 1st ovulation significantly influenced the length of the first cycle (Table 3 ) in

T a b le 2. Overall means, standard deviations and 50th, 75th and 90th percentiles for interval between calving and subsequent reproductive events.

\begin{tabular}{|c|c|c|c|c|c|c|}
\hline \multirow{2}{*}{$\begin{array}{l}\text { Interval from } \\
\text { calving to }\end{array}$} & \multirow[t]{2}{*}{$\mathbf{n}$} & \multirow[t]{2}{*}{ Mean } & \multirow[t]{2}{*}{$\mathbf{s}$} & \multicolumn{3}{|c|}{ Percentile } \\
\hline & & & & 50 (median) & 75 & 90 \\
\hline 1st ovulation & 291 & 26.5 & 22.9 & 19 & 30 & 50 \\
\hline Involution & $257^{\star}$ & 31.7 & 11.4 & 29 & 36 & 43 \\
\hline 1st ovulatory oestrus & 291 & 46.7 & 29.7 & 37 & 58 & 83 \\
\hline Regular functions & 291 & 49.7 & 28.3 & 41 & 59 & 85 \\
\hline Day of 1 st AI & 290 & 67.2 & 13.9 & 65 & 71 & 88 \\
\hline Day of conception & 271 & 95.3 & 39.3 & 84 & 117 & 158 \\
\hline
\end{tabular}

* For 34 cows the examination intervals were accidentally too infrequent to allow estimation of involution time.

T a ble 3. Length of the interval between 1st and 2nd postpartum ovulation in relation to interval from calving to 1st postpartum ovulation.

\begin{tabular}{lrrrrr}
\hline $\begin{array}{l}\text { Interval from } \\
\text { calving to 1st } \\
\text { ovulation, days }\end{array}$ & \multicolumn{5}{c}{$\begin{array}{c}\text { Percentages of cows, interval between 1st and 2nd ovulation } \\
\text { (days) }\end{array}$} \\
\cline { 2 - 6 } & $\mathrm{n}$ & $9-12$ & $13-16$ & $17-24$ & $\geq 25$ \\
\hline$\leq 15$ & 112 & 43 & 22 & 29 & 6 \\
$16-30$ & 110 & 25 & 14 & 55 & 6 \\
$31-45$ & 34 & 18 & 9 & 68 & 5 \\
$46-60$ & 18 & 17 & 0 & 78 & 5 \\
$\geq 61$ & 17 & 6 & 12 & 71 & 11 \\
\hline
\end{tabular}

The interval from calving to first ovulation was significantly related to the length of the interval between 1 st and 2 nd ovulation $\left(\chi^{2} ; \mathrm{P}<0.001\right)$. 
T a b l e 4. Overall mean and standard error (s.e.m.) for plasma levels $(\mathrm{pmol} / \mathrm{l})$ of 15-keto-13,14-dihydro-PGF ${ }_{2 \alpha}$ at day 10, 15 and 20 postpartum.

\begin{tabular}{lrrr}
\hline Days postpartum & $\mathrm{n}$ & Mean & s.e.m. \\
\hline 10 & 251 & 1027 & 45 \\
15 & 248 & 274 & 13 \\
20 & 240 & 181 & 9 \\
\hline
\end{tabular}

the sense that a large proportion of the early ovulating cows had a short interval between 1 st and 2 nd postpartum ovulations. The large variations were also very evident in plasma levels of 15-keto13,14-dihydro-PGF ${ }_{2 \alpha}$ (Table 4 ). There was a marked decline between days 10 and 15 postpartum and most cows were close to basal levels at 20 days postpartum.

The occurrence of external signs of heat increased with ovulation number (Table 5). The interval from calving to ovulation also influenced the occurrence of external signs of heat (Table 6). Post-oestrus bleedings occurred more frequently after the later postpartum ovulations and very few bleedings were detected after the 1st and 2nd ovulation (Table 5). Tre incidence of cows that showed external signs of heat without subsequent ovulation was high during the early postpartum period (Table 6). This was also reflected in the difference between the interval from calving to 1 st recorded oestrus and the interval from calving to 1 st ovulatory oestrus ( 33.6 vs. 44.7 days). Although the seasonal effects were non-significant $(P>0.05)$ there was a tendency that cows calving from October to March had longer intervals between calving and 1st oestrus than cows calving from April through September.

T a b l e 5. Occurrence of external signs of heat in relation to ovulations 1 to 5 postpartum and incidence of post oestrus bleeding after ovulation.

\begin{tabular}{lccc}
\hline \multirow{2}{*}{$\begin{array}{l}\text { Ovulation } \\
\text { number }\end{array}$} & $\mathrm{n}$ & \multicolumn{2}{c}{ Percentage of cows wiht } \\
\cline { 3 - 4 } 1 & 291 & signs of heat & postoestrus bleeding \\
\hline & 287 & 38.0 & 6.2 \\
3 & 265 & 78.4 & 27.9 \\
4 & 200 & 85.4 & 50.9 \\
5 & 121 & 90.0 & 60.5 \\
\hline
\end{tabular}


T a b l e 6. Occurrence of external signs of heat in relation to ovulations during the first 2 months after calving.

\begin{tabular}{|c|c|c|c|c|}
\hline \multirow[b]{2}{*}{ No. of cows with } & \multicolumn{4}{|c|}{ Days postpartum } \\
\hline & $<15$ & $16-30$ & $31-45$ & $46-60$ \\
\hline 1st ovulation & 112 & 110 & 34 & 18 \\
\hline Ovulation $2-5$ & 0 & 97 & 135 & 182 \\
\hline $\begin{array}{l}\% \text { with signs of } \\
\text { oestrus related to }\end{array}$ & & & & \\
\hline ovulation 1 & 4.5 & 41.8 & 50.0 & 88.9 \\
\hline ovulation $2-5$ & - & 73.2 & 67.4 & 70.9 \\
\hline $\begin{array}{l}\text { \% ovulation of all cows } \\
\text { with signs of oestrus }\end{array}$ & 26.3 & 68.9 & 55.4 & 67.8 \\
\hline
\end{tabular}

The influence of the indivioual cow was significant for the events measured with the exception of intervals between calving and first ovulation, 1st insemination and the number of AI per service period (Tables 7 and 8 ). Breed differences were significant for intervals between calving and first ovulation and calving to recorded uterine involution (Table 7). In both cases the SRB cows had the longest intervals and the SJB cows had the shortest

T a b l e 7. Least-squares (LS) means \pm standard errors (s.e.m.) for intervals between calving and subsequent reproductive events for cows of different breeds and parities.

\begin{tabular}{|c|c|c|c|c|}
\hline \multirow[b]{2}{*}{ Breed/Parity } & \multicolumn{4}{|c|}{ Interval (LS-means \pm s.e.m.) from calving to } \\
\hline & 1st ovulation & involution & 1st ov. oestrus & reg. functions \\
\hline SRB & $30.2 \pm 2.1 \mathrm{a}$ & $37.6 \pm 1.0^{a}$ & $51.5 \pm 2.5^{a}$ & $55.1 \pm 2.4 \mathrm{a}$ \\
\hline SLB & $24.3 \pm 3.5^{\mathrm{ab}}$ & $33.9 \pm 1.8 \mathrm{ab}$ & $39.1 \pm 4.4^{b}$ & $43.9 \pm 4.2^{b}$ \\
\hline $\mathbf{S R B} \times \mathbf{S L B}$ & $24.2 \pm 2.6^{\mathrm{ab}}$ & $30.6 \pm 1.3 \mathrm{bc}$ & $41.4 \pm 3.2^{b}$ & $45.2 \pm 3.1 \mathrm{~b}$ \\
\hline SJB & $18.8 \pm 2.6^{b}$ & $27.3 \pm 1.3 \mathrm{c}$ & $43.6 \pm 3.4 \mathrm{ab}$ & $45.4 \pm 3.3^{b}$ \\
\hline 1 & $27.7 \pm 3.2$ & $28.2 \pm 1.6 \mathrm{~d}$ & $42.6 \pm 3.9$ & $45.0 \pm 3.7$ \\
\hline 2 & $22.7 \pm 2.3$ & $29.1 \pm 1.1 \mathrm{~d}$ & $44.8 \pm 2.9$ & $47.2 \pm 2.7$ \\
\hline 3 & $21.8 \pm 2.8$ & $36.2 \pm 1.3 \mathrm{e}$ & $44.7 \pm 3.4$ & $49.2 \pm 3.3$ \\
\hline $4+5$ & $29.7 \pm 3.6$ & $39.4 \pm 1.7 \mathrm{e}$ & $50.7 \pm 4.5$ & $55.1 \pm 4.3$ \\
\hline \multicolumn{5}{|c|}{ Level of significance for } \\
\hline Cow & N.S. & ** & $\star \star \star$ & 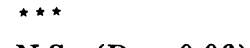 \\
\hline Breed & $\star$ & $\star \star \star$ & N.S. & N.S. $(P=0.06)$ \\
\hline Parity & N.S. & $\star \star \star *$ & N.S. & N.S. \\
\hline $\mathrm{R}^{2}$ & 0.14 & 0.49 & 0.28 & 0.29 \\
\hline
\end{tabular}

a, b, c, d, e, LS-means with main effect with unlike superscripts differ $(\mathrm{P}<0.05)$.

${ }^{\star} \mathrm{P}<0.05 ;{ }^{\star \star} \mathrm{P}<0.01 ;{ }^{\star \star}{ }^{\star} \mathrm{P}<0.001$. 
intervals and SLB and crossbred cows appeared to be intermediates between SRB and SJB cows. Although non-significant, the SRB cows had longer intervals between calving and regular reproductive functions than any of the other breeds (Table 7).

The parity of the cow significantly influenced the interval from calving to recorded uterine involution (Table 7) and there was a tendency for longer intervals between calving and first ovulation for primiparous cows and 4 th and 5 th calvers.

The interval from calving to first AI was similar for all breeds and parities and this was expected since all cows were inseminated at first normal heat $\geq 50$ days postpartum and $75 \%$ of all cows (Table 2) had their first ovulatory oestrus within 58 days after calving.

The final conception rate and the average number of AI per service period were highest and lowest respectively for the SJB cows whereas the highest number of AI per service period was found for the SLB cows (Table 8). The shortest calving to conception intervals were found for crossbred and SJB cows.

Most of the events studied were significantly correlated to each other (Table 9). High correlations should be expected be-

T a b l e 8. Least-squares (LS) means \pm standard errors (s.e.m.) for fertility measures in relation to cow, breed and parity.

\begin{tabular}{|c|c|c|c|c|}
\hline \multirow[b]{2}{*}{ Breed/Parity } & \multicolumn{2}{|c|}{$\frac{\text { Interval (LS-mean } \pm \text { s.e.m.) }}{\text { from calving to }}$} & \multirow{2}{*}{$\begin{array}{l}\text { No. of AI/service } \\
\text { period } \\
\text { LS-mean } \pm \text { s.e.m. }\end{array}$} & \multirow{2}{*}{$\begin{array}{l}\text { Final conception } \\
\text { rate }(\%) \\
\text { Overall mean }\end{array}$} \\
\hline & $\begin{array}{l}\text { from calv } \\
1 \text { st AI }\end{array}$ & & & \\
\hline SRB & $69.3 \pm 1.4^{a}$ & $101.8 \pm 4.1 \mathrm{a}$ & $2.16 \pm 0.13 \mathrm{abc}$ & 87.6 \\
\hline SLB & $64.8 \pm 2.4 \mathrm{ab}$ & $102.3 \pm 7.1 \mathrm{ac}$ & $2.45 \pm 0.22^{b}$ & 90.2 \\
\hline $\mathrm{SRB} \times \mathrm{SLB}$ & $64.8 \pm 1.8^{b}$ & $84.9 \pm 5.2^{\mathrm{b}}$ & $1.89 \pm 0.16^{a c}$ & 84.9 \\
\hline SJB & $66.9 \pm 1.9 \mathrm{ab}$ & $93.4 \pm 5.1 \mathrm{abc}$ & $1.76 \pm 0.17 \mathrm{a}$ & 98.2 \\
\hline 1 & $63.7 \pm 2.1$ & $90.6 \pm 5.9$ & $1.86 \pm 0.20$ & 90.6 \\
\hline 2 & $65.8 \pm 1.6$ & $95.5 \pm 4.5$ & $2.17 \pm 0.15$ & 89.9 \\
\hline 3 & $68.3 \pm 1.9$ & $100.2 \pm 5.5$ & $2.09 \pm 0.17$ & 90.5 \\
\hline $4+5$ & $70.7 \pm 2.5$ & $98.7 \pm 7.3$ & $2.09 \pm 0.23$ & 90.0 \\
\hline \multicolumn{5}{|c|}{ Level of significance for } \\
\hline Cow & N.S. & * & N.S. & 一 \\
\hline Breed & N.S. & N.S. & N.S. & - \\
\hline Parity & N.S. & N.S. & N.S. & 一 \\
\hline $\mathrm{R}^{2}$ & 0.04 & 0.23 & 0.09 & 一 \\
\hline
\end{tabular}

a, b, c, LS-means within main effect with unlike superscripts differ $(\mathrm{P}<0.05)$. 
Table 9. Phenotypic within cow correlations ( $r$ ) between various measures of postpartum reproductive performance.

\begin{tabular}{lcc}
\hline Intervals correlated & $\mathrm{r}$ & $\begin{array}{c}\text { Levels of } \\
\text { significance }\end{array}$ \\
\hline 1st ovulation - uterine involution & 0.31 & $\star \star \star$ \\
1st ovulation - 1st ovulatory oestrus & 0.48 & $\star \star \star$ \\
1st ovulation - reg. functions & 0.48 & $\star \star \star$ \\
Involution - 1st ovulatory oestrus & 0.09 & $\mathrm{~N} . \mathrm{S}$. \\
Involution - reg. functions & 0.22 & $\star$ \\
1st ovulatory oestrus - reg. functions & 0.97 & $\star \star \star$ \\
Reg. functions - 1st AI & 0.26 & $\star \star$ \\
\hline
\end{tabular}

tween time from calving to regular reproductive functions, uterine involution and first ovulatory oestrus due to the definition of the term regular reproductive functions. The highest correlation was found between 1 st ovulatory oestrus and regular reproductive functions which indicate that first ovulatory oestrus is the most important factor affecting variations in the interval between calving and regular functions. However, the results also indicate a significant relationship between onset of ovarian cyclicity and uterine involution.

The overall inciaence of reproductive disorders was low in the material. Retained placenta occurred more frequently among the older cows (Table 10) and 5 out of 10 cows developed endometritis after placental retention. Endometritis, without placental retention, also occurred more frequently among the older cows and with the highest indicence among the SRB cows. Cystic ovaries were of 3 categories, i.e. those palpated that disappeared

T a b l e 10 . Numbers of cows with retained placenta, endometritis or ovarian cysts in relation to breed and parity of the cows.

\begin{tabular}{|c|c|c|c|c|c|c|c|c|}
\hline \multirow[b]{2}{*}{ Diagnosis } & \multicolumn{4}{|c|}{ Parity } & \multicolumn{4}{|c|}{ Breed } \\
\hline & 1 & 2 & 3 & $4+5$ & SRB & $\begin{array}{l}\text { SRB } \times \\
\text { SLB }\end{array}$ & SLB & SJB \\
\hline No. of animals & 89 & 82 & 70 & 50 & 114 & 65 & 53 & \\
\hline Retained placenta & 3 & 一 & 3 & 4 & 5 & 2 & 3 & - \\
\hline Endometritis & 2 & 4 & 3 & 7 & 11 & 1 & 4 & - \\
\hline $\begin{array}{l}\text { Cystic ovaries } \\
\text { untreated }\end{array}$ & 4 & 3 & 2 & 1 & 5 & 1 & - & 4 \\
\hline ruptured & - & 5 & 4 & 1 & 4 & 5 & 1 & - \\
\hline hormone treated & - & 3 & 4 & 5 & 12 & - & 一 & 一 \\
\hline
\end{tabular}


without treatment, those that were ruptured accidentally or as a treatment without further problems, and those that needed hormonal treatment for recovery. Among the primiparous cows only spontaneous recovery was found, whereas among the older cows all categories of cysts occurred. Hormonal treatment was needed only in SRB cows with the highest incidence among 4th and 5th calvers. Two cows had cysts during three consecutive postpartum periods and 5 cows had cysts during two consecutive periods. It is worth mentioning that two monozygous twins of the SRB breed developed cysts and endometritis in combination with vaginal prolapses after their 2 nd or 3 rd calving.

\section{DISCUSSION}

The aim of the present study was to give a description of the reproductive events during the bovine postpartum period from a clinical and practical point of view. Thus, days of ovulations are estimates rather than absolute determinations and with the examination schedule applied involution periods were somewhat overestimated. However, all comparisons were made among animals treated identically and the results might be applied as a basis for clinical work as well as for managerial decisions.

The average interval from calving to first ovulation is similar to the results of other studies (e.g. Marion \& Gier 1968, Morrow et al. 1969b, King et al. 1976, Fonseca et al. 1983). However, abnormal luteal phases as indicated by milk progesterone levels, in studies by e.g. Bulman \& Wood (1980) and Laitinen (1983) were not detected. For practical purposes the significant breed differences are important and furthermore averages are less important than the actual distribution of the individual values, mainly because of the skewed disttibution that were found.

Short cycles after the first postpartum ovulation have been found in several studies (Morrow et al. 1966, Marion \& Gier 1968, Morrow et al. 1969b, Morrow 1971, Kindahl et al. 1982). The present data indicate that a high incidence of $9-12$ day cycles among early ovulating cows is a major reason for the shorter average intervals between 1 st and 2 nd ovulation. Data presented by Kindahl et al. (1982) indicate that termination of the first luteal phase is by elevated levels of prostaglandins concomitant with lowered progesterone levels. Since the majority of short cycles occurred during the time of uterine involution it is tempt- 
ing to speculate that uterine prostaglandin release is more easily induced during the process of involution than after completed involution. However, also in late-ovulating cows a few short cycles were found.

The average intervals between calving and recorded uterine involution reported here are somewhat longer than in previous studies (e.g. Rasbech 1950, Morrow et al. 1966, Morrow et al. 1969c, Moller 1970, Lindell et al. 1982). This would partly be explained by the relatively long examination intervals used. An additional explanation might be that the clinical criteria used demanded that size reduction of the uterus was completed. Again, the breed differences are of practical importance. The differences between parities are similar to results presented by Morrow et al. (1969c) and Fonseca et al. (1983). Lindell et al. (1982) found a significant relationship between involution time and duration of postpartum prostaglandin release. The present study does not allow a similar analysis. However, the number of cows with plasma levels of the prostaglandin metabolite below $500 \mathrm{pmol} / \mathrm{l}$ at day 10 postpartum increased with parity. Thus there might be a relationship between duration of prostaglandin release and involution time also in the present material.

In most of the postpartum periods first ovulation occurred before the first ovulatory oestrus which is in agreement with results of previous studies (e.g. Morrow et al. $1969 \mathrm{~b}$, Whitmore et al. 1974). To get an indication of the time after calving at which the cows could be inseminated with a reasonable possibility of conception, the term "regular reproductive functions" was introduced. The fact that all cows fulfilling the present criteria continued to cycle or conceived, indicates that a proper terminology had been chosen. It is also clear from the results that ovulatory oestrus, for most of the cows, was the last event that occurred before they had regular reproductive functions and only in a few cases was uterine involution later than ovulatory oestrus. Thus, the expression of external signs of heat in relation to ovulation is from a practical point of view a very important factor in the normalization of reproductive functions after calving. In a previous study, utilizing the same material, it was found that cows that were ketopositive at two or more weekly examinations had longer periods from calving to regular reproductive functions (Berglund \& Larsson 1983). Thus, metabolic factors might partly explain the large individual variations found. 
In agreement with previous studies (Morrow et al. 1969b, King et al. 1976) the frequency of cows with external signs of heat increased with ovulation number as well as with increasing time after calving. The present results might indicate that the time lapse after calving is just as important as the ovulation number. Since postoestrus bleeding was always followed by conception or formation of a CL/progesteron rise, it might be used as a confirmation of ovulation and, from 3rd ovulation and onwards, the incidence of bleeding was high enough to be of practical importance.

The incidence of reproductive disorders was on the same level as in commercial Swedish herds. However, since the animal material was limited, no statistical analysed were performed specifically on these cows. The high incidence of endometritis after placental retention is remarkable, as well as the fact that cystic ovaries requiring hormonal treatment were only found in pluriparous SRB cows. The majority of the cows with ovarian cysts or endometritis were ketopositive on 2 or more occasions (Berglund \& Larsson 1983).

In conclusion, the present results indicate that the individual animal exerts a great influence on postpartum reproductive functions, especially on the measures that are important for early successful inseminations. Breed differences were most apparent for onset of ovarian activity and uterine involution. In most comparisons the SRB cows had the slowest and the SJB cows the fastest normalization of reproductive functions and, furthermore, few SJB cows had endometritis or ovarian cysts. The lack of correspondence between ovarian activity and external signs of heat seems to be a most important limiting factor for the possibility to shorten calving intervals by early postpartum breeding.

\section{ACKNOWLEDGEMENT}

This study was supported by grants from the Swedish Council for Forestry and Agricultural Research.

\section{REFERENCES}

Berglund, B., E. Brännäng, T. Henningsson, L. Jansson, G. Josefsson, G. Lindkvist, B. Magnusson, J. Philipsson \& C. Swensson: Comprehensive experiments on traits affecting longevity in Swedish dairy cattle breeds. I. Experimental design and general description of the experiment. Swedish J. agric. Res. 1980, 10, $159-166$. 
Berglund, B., L.-E. Edqvist, L. Jansson, H. Kindahl, K. Larsson, A. Malmqvist \& C. Swensson: Reproductive performance of dairy cows from parturition to conception. Rep. 31st Ann. Meet. EAAP, Zagreb 1980, 5 pp.

Berglund, B. \& K. Larsson: Milk ketone-bodies and reproductive performance in post partum dairy cows. Proc. Vth Int. Conf. on Prod. Dis. in Farm Animals, Uppsala 1983, p. 153-157.

Britt, J. H.: Early postpartum breeding in dairy cows: A review. J. Dairy Sci. 1975, 58, 266-271.

Bulman, D. C. \& P. D. P. Wood: Abnormal patterns of ovarian activity in dairy cows and their relationship with reproductive performance. Anim. Prod. 1980, 30, 177-188.

Fonseca, F. A., J. H. Britt, B. T. McDaniel, J. C. Wild \& A. H. Rakes: Reproductive traits of Holsteins and Jerseys. Effect of age, milk yield and clinical abnormalities on involution of cervix and uterus, ovulation, eostrous cycles, detection of oestrus, conception rate, and days open. J. Dairy Sci. 1983, 66, 1128-1147.

Garcia, M.: Reproductive functions during the post partum period in the cow. A review of the literature. Nord. Vet.-Med. 1982, 34, $264-275$.

Garcia, M. \& K. Larsson: Clinical findings in post partum dairy cows. Nord. Vet.-Med. 1982, 34, 255-263.

Graves, W. D., J. W. Lauderdale, J. W. Riesen, S. Saiduddin, L. E. Casida, E. R. Hauser \& W. J. Tyler: Studies on the postpartum cow. Research Bulletin, Coll. of Agric. and Life Sci., University of Wisconsin 1968, 270, 1-54.

Helwig, J. T. \& K. A. Council (eds.) : SAS User's Guide. SAS Institute Inc., Raleigh, North Carolina 1979.

Kindahl, H., L.-E. Edqvist, E. Granström \& A. Bane: The release of prostaglandin $\mathrm{F}_{2 \alpha}$ as reflected by 15-keto-13,14-dihydroprostaglandin $\mathrm{F}_{2 \alpha}$ in the peripheral circulation during normal luteolysis in heifers. Prostaglandins 1976, 11, 871-878.

Kindahl, H., L.-E. Edqvist, K. Larsson \& A. Malmqvist: Influence of prostaglandins on ovarian function postpartum. In "Factors Influencing Fertility in the Postpartum Cow" (eds. H. Karg \& E. Schallenberger), Martinus Nijhoff Publishers, The Hague, Current Topics in Veterinary Medicine and Animal Science 1982, 20, 173-196.

King, G. J., J. F. Hurnik \& H. A. Robertson: Ovarian function and estrus in dairy cows during early lactation. J. Anim. Sci. 1976, $42,688-692$.

Laitinen, J.: Oestrous confirmation, pregnancy diagnosis and postpartum ovarian follow-up of the Finnish dairy cows by milk progesterone assay: Effect of breed, season, feed and sampling on milk progesterone levels. Thesis, University of Kuopio 1983, $108 \mathrm{pp}$.

Larsson, K., H. Kindahl, A. Malmqvist, L.-E. Edqvist \& L. Janson: Post partum periodens förlopp hos förstakalvande mjölkkor. (The 
postpartum period in primiparous dairy cows). Proc. XIV Nord. Vet. Congr., Copenhagen 1982, 327-331.

Lindell, J.-O., H. Kindahl, L. Janson \& L.-E. Edqvist: Post-partum release of prostaglandin $F_{2 \alpha}$ and uterine involution in the cow. Theriogenology 1982, 17, 237—245.

Marion, G. B. \& H. T. Gier: Factors affecting bovine ovarian activity after parturition. J. Anim. Sci. 1968, 27, 1621-1626.

Moller, $K$.: Uterine involution and ovarian activity after calving. N. Z. Vet. J. 1970, 18, 140-145.

Morrow, D. A.: Effects of periparturient disease on postpartum reproduction in dairy cattle. J. Anim. Sci. 1971, 32 (suppl. 1), 17-21.

Morrow, D. A., S. J. Roberts, K. McEntee \& H. G. Gray: Postpartum ovarian activity and uterine involution in dairy cattle. J. Amer. vet. med. Ass. 1966, 149, 1596-1609.

Morrow, D. A., S. J. Roberts \& K. McEntee: A review of post-partum ovarian activity and involution of the uterus and cervix in cattle. Cornell Vet. 1969 a, 59, 134-154.

Morrow, D. A., S. J. Roberts \& K. McEntee: Postpartum ovarian activity and involution of the uterus and cervix in dairy cattle. I. Ovarian activity. Cornell Vet. 1969 b, 59, 173-190.

Morrow, D. A., S. J. Roberts \& K. McEntee: Postpartum ovarian activity and involution of the uterus and cervix in dairy cattle. II. Involution of uterus and cervix. Cornell Vet. $1969 \mathrm{c}, 59,190-198$.

Pease, A. H. R.: Note on the measurement of accuracy of prediction equations. Pig Ind. Developm. Authority Statist. Sect. 3. U.K. Bletchley 1966.

Rasbech, N. O.: The normal involution of the uterus in the cow. Nord. Vet.-Med. 1950, 2, 655-687.

SHS (Association for Swedish Livestock Breeding and Production): Annual Report 1982, 1983, 48 p.

Whitmore, H. L., W. J. Tyler \& L. E. Casida: Effects of early postpartum breeding in dairy cattle. J. Anim. Sci. 1974, 38, 339-346.

Zeddies, J.: Special economic aspects of fertility related to central European farming conditions. In "Factors Influencing Fertility in the Postpartum Cow" (eds. H. Karg \& E. Schallenberger), Martinus Nijhoff Publishers, The Hague, Current Topics in Veterinary Medicine and Animal Science 1982, 20, 425—441.

\section{SAMMANFATTNING}

Könsfunktionerna under postpartumperioden hos mjölkkor. I: Inflytande av djur, ras och kalvningsnummer.

Ändamålet med föreliggande undersökning var att studera inflytandet av djur, ras och kalvningsnummer på könsfunktionerna under postpartumperioden hos mjölkkor. Totalt ingick 141 kor i undersökningen, som var en del av en studie över egenskaper som påverkar hållbarheten hos svenska mjölkkor. Korna tillhörde 4 olika rasgrupper och de kalvade 1: a till 5:e gången under undersökningsperioden. Un- 
dersökningen pågick under 3 år och 44 kor undersöktes efter 1 kalvning, 49 kor efter 2 kalvningar, 43 kor efter 3 kalvningar och 5 kor efter 4 kalvningar.

Korna undersöktes kliniskt, genom rektalpalpation, var 10:e dag från kalvning till första insemination, som gjordes vid första brunst mer än 50 dagar efter kalvning. Yttre brunstsymptom registrerades av djurskötarna 3 gånger dagligen. Blodprover för analys av progesteron i plasma togs dag 10, 15 och 20 efter kalvning och därefter var 10:e dag till första insemination. Blodprover tagna dag 10, 15 och 20 analyserades också med avseende på 15-keto-13,14-dihydro-PGF $2 \alpha$.

Registrerade brunstsymptom, kliniska observationer och progesteronnivåer sammanställdes för varje postpartumperiod och grundat på detta beräknades intervall från kalvning till ovulationer, registrerad livmoderinvolution, första och senare brunster samt regulariserade könsfunktioner. Statistisk utvärdering av data gjordes med hjälp av leastsquares analys.

Resultaten visar på en avsevärd variation inom och mellan djur beträffande könsfunktionerna efter kalvning. I hela materialet inträffade den första ovulationen, efter kalvning, före avslutad livmoderinvolution och det förelåg ett nära samband mellan första ovulatoriska brunst och regulariserade könsfunktioner. Intervallet mellan kalvning och första ovulation påverkade längden av den första sexualcykeln i så måtto att en stor del av de tidigt ovulerande korna hade ett kort intervall mellan första och andra ovulation. De stora variationerna var också uppenbara vad avser plasmanivåerna av 15-keto-13,14-dihydro$\mathrm{PGF}_{2 \alpha}$. En markant sänkning sågs mellan dag 10 och 15 postpartum och flertalet kor hade nått basala nivåer dag 20 efter kalvning.

Den individuella kon påverkade signifikant intervallen mellan kalvning och; registrerad livmoderinvolution, 1:a brunst med ovulation, regulariserade könsfunktioner samt konception. Rasinflytandet var signifikant för intervallen mellan kalvning och första ovulation samt registrerad livmoderinvolution medan kalvningsnumret endast påverkade intervallet mellan kalvning och avslutad livmoderinvolution.

(Received June 18, 1984).

Reprints may be requested from: Kjell Larsson, the Department of Obstetrics and Gynaecology, Faculty of Veterinary Medicine, Swedish University of Agricultural Sciences, S-750 07 Uppsala, Sweden. 